\title{
Cognitive interventions in healthy older adults and people with mild cognitive impairment : a systematic review
}

Citation for published version (APA):

Reijnders, J., van Heugten, C., \& van Boxtel, M. (2013). Cognitive interventions in healthy older adults and people with mild cognitive impairment : a systematic review. Ageing Research Reviews, 12(1), $263-275$. https://doi.org/10.1016/j.arr.2012.07.003

Document status and date:

Published: 01/01/2013

DOI:

10.1016/j.arr.2012.07.003

Document Version:

Publisher's PDF, also known as Version of record

\section{Document license:}

Taverne

\section{Please check the document version of this publication:}

- A submitted manuscript is the version of the article upon submission and before peer-review. There can be important differences between the submitted version and the official published version of record.

People interested in the research are advised to contact the author for the final version of the publication, or visit the DOI to the publisher's website.

- The final author version and the galley proof are versions of the publication after peer review.

- The final published version features the final layout of the paper including the volume, issue and page numbers.

Link to publication

\footnotetext{
General rights rights.

- You may freely distribute the URL identifying the publication in the public portal. please follow below link for the End User Agreement:

www.umlib.nl/taverne-license

Take down policy

If you believe that this document breaches copyright please contact us at:

repository@maastrichtuniversity.nl

providing details and we will investigate your claim.
}

Copyright and moral rights for the publications made accessible in the public portal are retained by the authors and/or other copyright owners and it is a condition of accessing publications that users recognise and abide by the legal requirements associated with these

- Users may download and print one copy of any publication from the public portal for the purpose of private study or research.

- You may not further distribute the material or use it for any profit-making activity or commercial gain

If the publication is distributed under the terms of Article $25 \mathrm{fa}$ of the Dutch Copyright Act, indicated by the "Taverne" license above, 
Review

\title{
Cognitive interventions in healthy older adults and people with mild cognitive impairment: A systematic review
}

\author{
Jennifer Reijnders ${ }^{\mathrm{a}, *}$, Caroline van Heugten ${ }^{\mathrm{a}, \mathrm{b}}$, Martin van Boxtel ${ }^{\mathrm{a}, \mathrm{b}}$ \\ a Department of Psychiatry and Neuropsychology, School for Mental Health and Neuroscience, Maastricht University Medical Centre, Maastricht, The Netherlands \\ ${ }^{\mathrm{b}}$ Department of Neuropsychology and Psychopharmacology, Faculty of Psychology and Neurosciences, Maastricht University, Maastricht, The Netherlands
}

\section{A R T I C L E I N F O}

\section{Article history:}

Received 11 April 2012

Received in revised form 13 July 2012

Accepted 17 July 2012

Available online 25 July 2012

\section{Keywords:}

Systematic review

Cognitive interventions

Healthy older adults

Mild cognitive impairment

Randomized controlled trials

\begin{abstract}
A B S T R A C T
Given that the research area of cognitive intervention studies in the aging population is growing rapidly, it is important to review and gauge more recent intervention studies, in order to determine the evidence for the effectiveness of cognitive interventions. The purpose of the present review was to update the recent systematic reviews of Papp et al. (2009) and Martin et al. (2011), to evaluate the effectiveness of cognitive interventions in healthy older adults and people with $\mathrm{MCI}$, by taking into account the methodological quality of the interventions studies. A systematic review of randomized controlled trials (RCT) and clinical studies published between August 2007 and February 2012 in Pubmed and PsychINFO was performed. The quality of the included RCTs was assessed according to the CONSORT criteria for RCTs. A total of thirty-five studies were included; twenty-seven RTCs and eight clinical studies. The content of the intervention studies differed widely, as did the methodological quality of the included RCTs, but was considerably low with an average of $44 \%$ of the Consort items included. The results show evidence that cognitive training can be effective in improving various aspects of objective cognitive functioning; memory performance, executive functioning, processing speed, attention, fluid intelligence, and subjective cognitive performance. However, the issue whether the effects of cognitive interventions generalize to improvement in everyday life activities is still unresolved and needs to be addressed more explicitly in future research.
\end{abstract}

(c) 2012 Elsevier B.V. All rights reserved.

\section{Introduction}

The proportion of older individuals in our western society is growing rapidly (CBS, 2009). As a consequence a larger amount of people encounter difficulties in executive functioning, memory, and speed of information processing (Glisky, 2007). It is an ongoing debate whether such difficulties can be postponed or even reverted in a normal aging population, but overall the general held opinion among researchers in this field has been optimistic (Lustig et al., 2009; Valenzuela and Sachdev, 2009). Cognitive training programs, involving guided practice of specific cognitive tasks, and cognitive stimulation programs, aimed at enhancing general cognitive functioning, have been offered to prevent or minimize the effects of cognitive aging. The effects of such cognitive interventions were investigated not only in healthy older adults, but also in people with cognitive deterioration beyond the normal age-dependent changes,

\footnotetext{
* Corresponding author at: Maastricht University, School for Mental Health and Neuroscience, Department of Psychiatry and Neuropsychology, PO Box 616, 6200 MD Maastricht, The Netherlands. Tel.: +31 43 3881029; fax: +31 433884092.

E-mail address: jennifer.reijnders@maastrichtuniversity.nl (J. Reijnders).
}

for example people with mild cognitive impairment (MCI) (Lustig et al., 2009; Valenzuela and Sachdev, 2009).

In the last decade several reviews have been conducted into the effects of cognitive interventions in healthy older adults and people with MCI (Valenzuela and Sachdev, 2009; Jean et al., 2010a; Martin et al., 2011; Papp et al., 2009; Tardif and Simard, 2011; Teixeira et al., 2012). Papp et al. (2009) performed a systematic review with meta-analytic techniques to analyze randomized controlled trials (RCT) of cognitive interventions in healthy older adults. Ten RCTs published between 1996 and 2007 were included and analyzed in their review. A mean effect size of 0.16 was found across all outcome measures. Effect sizes were larger when outcome measures were directly related to type of training. Their conclusion was that training improves immediate performance on related tasks but there was no evidence for generalization effects to overall cognitive functioning. They also stated that their review was limited by small and heterogeneous studies with low methodologically quality and more RCTs are needed with sufficient follow-up time, matched active control groups and outcome measures that can show changes in more than one specific domain (Papp et al., 2009). The review of Martin et al. (2011) included, in comparison to Papp et al. (2009), more studies from both healthy older adults and MCI populations. A total of thirty-six RTCs were included, 


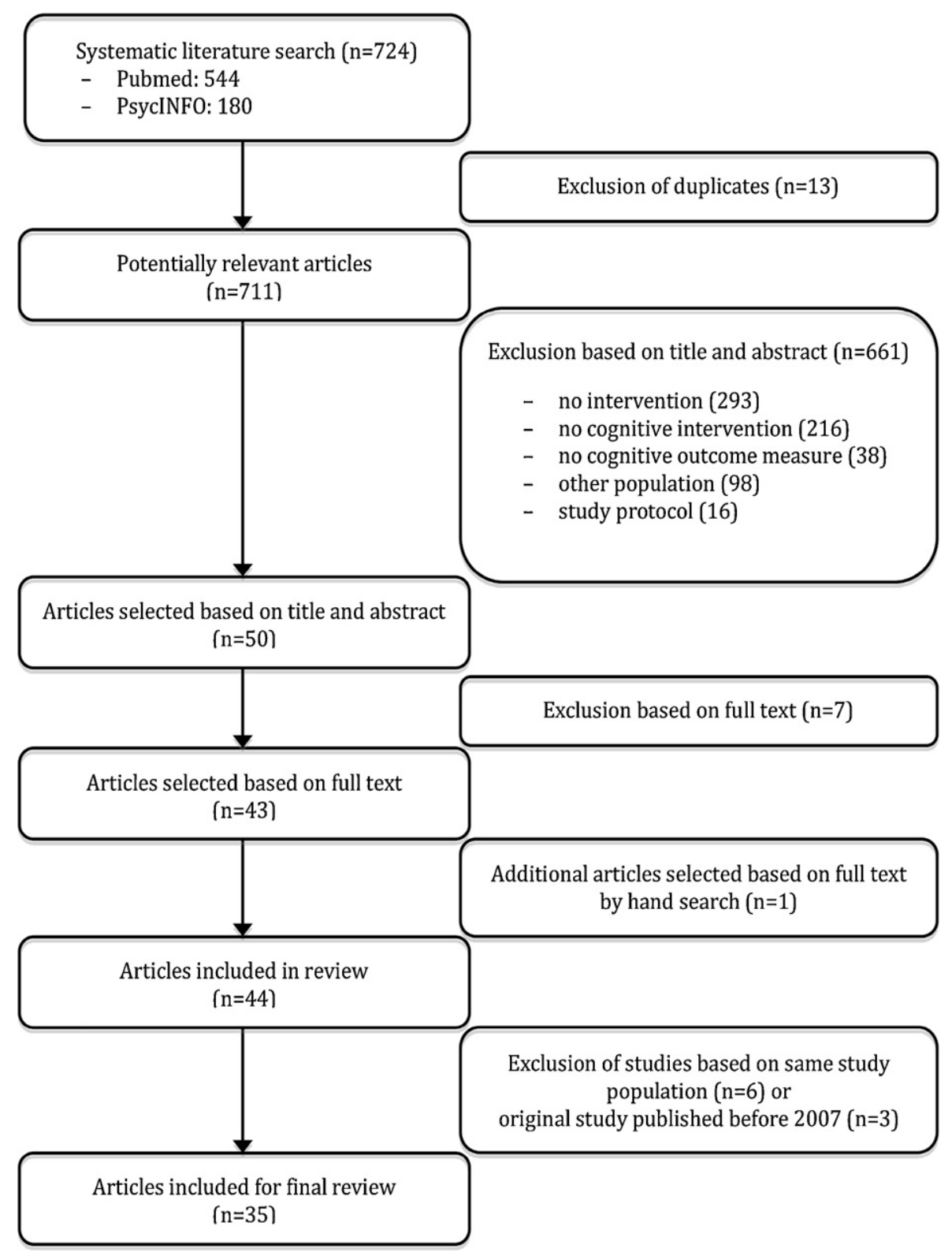

Fig. 1. Selection process of the systematic review.

published between 1985 and 2007. Only data on memory training could be pooled. Results showed that, for healthy older adults, immediate and delayed verbal recall improved significantly through training compared to a no-treatment control group. When compared to an active control condition, the improvements were no longer significant. For individuals with $\mathrm{MCI}$, the analysis demonstrated the same pattern (Martin et al., 2011). Only quite recently, a review of Tardif and Simard (2011) was published, who reviewed cognitive interventions in healthy older adults and included fourteen studies, published between 2001 and March 2011. Their conclusion was that improvements were observed on at least one outcome measure in each study. They also noted that the quality and content of the studies included were very heterogeneous and difficult to compare which made generalization to everyday life rather difficult (Tardif and Simard, 2011).

Given that the research area of cognitive intervention studies is growing rapidly, it is important to review and gauge more recent intervention studies in both healthy older adults and people with $\mathrm{MCI}$, in order to determine the evidence for the effectiveness of cognitive interventions. In doing so, it is important to recognize that one should consider the heterogeneity in quality and content of the studies and interventions and to include not only objective outcome measures (e.g. test performance) but also the subjective outcome of such interventions (e.g. cognitive complaints). The purpose of the present review was therefore to evaluate the effectiveness of cognitive interventions in healthy older adults and people with $\mathrm{MCI}$, by taking into account the content and methodological quality of the interventions studies.

\section{Methods}

A systematic literature search for cognitive intervention studies was done in two databases: Pubmed and PsychINFO. Our search included studies that were performed between August 1, 2007 and February 14, 2012, as we wanted to build on the results of two earlier performed systematic reviews (Martin et al., 2011; Papp et al., 2009). Our initial search strategy included the intersection of the following terms: ['cognitive intervention' OR 'cognitive training' OR 
Table 1

Intervention characteristics of studies in healthy older adults $(n=21)$.

\begin{tabular}{|c|c|c|c|c|c|}
\hline Study & Aim of intervention & Intervention & Duration & $\begin{array}{l}\text { Total hours of } \\
\text { intervention }\end{array}$ & Control group \\
\hline Bailey et al. (2010) & $\begin{array}{l}\text { Improving ability to regulate } \\
\text { learning }\end{array}$ & $\begin{array}{l}\text { Training metacognitive skills at home such as } \\
\text { self-testing and efficient time allocation }\end{array}$ & $\begin{array}{l}2 \text { weeks manual with lessons } \\
\text { and } 4 \text { assignments }\end{array}$ & NC & Waiting list \\
\hline Basak et al. (2008) & To improve executive functions & $\begin{array}{l}\text { A real-time strategy game (rise of nation) that } \\
\text { combines the speed of real-time gaming and the } \\
\text { complexity of strategy games }\end{array}$ & $\begin{array}{l}15 \text { training sessions of } 1.5 \mathrm{~h} \\
4-5 \text { weeks }\end{array}$ & $22.5 \mathrm{~h}$ & $\begin{array}{l}\text { No training and no } \\
\text { contact }\end{array}$ \\
\hline Berry et al. (2010) & To improve perceptual abilities & $\begin{array}{l}\text { Visual cognitive training using the Sweep Seeker } \\
\text { program (Posit science) }\end{array}$ & $\begin{array}{l}3-5 \text { sessions per week. Total of } \\
10 \mathrm{~h} \text { training }\end{array}$ & $10 \mathrm{~h}$ & No training \\
\hline Borella et al. (2010) & $\begin{array}{l}\text { To improve performance on } \\
\text { WM tasks and generalization } \\
\text { to untrained task }\end{array}$ & $\begin{array}{l}\text { Verbal WM training using the categorization working } \\
\text { memory span task }\end{array}$ & 3 sessions of $60 \mathrm{~min}$ & $3 \mathrm{~h}$ & Active control \\
\hline Bottiroli and Cavallini (2009) & $\begin{array}{l}\text { Improve the use of memory } \\
\text { strategies and transfer effects } \\
\text { to non-practiced tasks }\end{array}$ & $\begin{array}{l}\text { Teaching } 2 \text { memory strategies and practicing on } 3 \\
\text { computerized memory tasks which were adapted from } \\
\text { the neuropsychological training software }\end{array}$ & 3 sessions of $2 \mathrm{~h}$ & $6 \mathrm{~h}$ & Waiting list \\
\hline Buiza et al. (2008) & $\begin{array}{l}\text { To improve cognitive functions } \\
\text { and quality of life }\end{array}$ & $\begin{array}{l}\text { Cognitive therapy based on Braak and Braak's model of } \\
\text { Alzheimer's staging addressing memory, attention, } \\
\text { language, visuoconstructive ability, executive } \\
\text { functions, visuo-motor coordination, and praxis (EG1 } \\
\text { and 2). In EG1 issues related to well-being were } \\
\text { discussed }\end{array}$ & 2 years, total of 180 session & $270 \mathrm{~h}$ & No training \\
\hline Buschkuehl et al. (2008) & $\begin{array}{l}\text { To improve memory } \\
\text { performance in old-old adults }\end{array}$ & Computerized WM training & $\begin{array}{l}3 \text { months } \\
2 \text { sessions per week of } 45 \mathrm{~min}\end{array}$ & $18 \mathrm{~h}$ & $\begin{array}{l}\text { Active control } \\
\text { (physical } \\
\text { intervention) }\end{array}$ \\
\hline Carlson et al. (2008) & $\begin{array}{l}\text { To enhance physical, social, } \\
\text { and cognitive activity and, in } \\
\text { doing so, exercise memory and } \\
\text { executive functions }\end{array}$ & $\begin{array}{l}\text { Community-based program 'Experience Corps' to help } \\
\text { elementary school children with reading achievement, } \\
\text { library support and classroom behavior }\end{array}$ & $\begin{array}{l}1 \text { year } \\
15 \mathrm{~h} \text { per week }\end{array}$ & $630 \mathrm{~h}$ & Waiting list \\
\hline Cavallini et al. (2010) & $\begin{array}{l}\text { Instruction-based memory } \\
\text { training to promote transfer } \\
\text { effects to other memory tasks }\end{array}$ & $\begin{array}{l}\text { Training in mnemonics (EG1) and in EG2: also } \\
\text { instructions how to apply these to other tasks, imagery } \\
\text { and sentence generation were practiced }\end{array}$ & 4 sessions of $2 \mathrm{~h}$ & $8 \mathrm{~h}$ & No training \\
\hline Fairchild and Scogin (2010) & $\begin{array}{l}\text { To improve both objective and } \\
\text { subjective memory }\end{array}$ & $\begin{array}{l}\text { Memory enhancement program addressing objective } \\
\text { and subjective memory; information about aging } \\
\text { process; nutrition; mood; controllability of memory } \\
\text { and teaching mnemonics }\end{array}$ & $\begin{array}{l}6 \text { weeks } \\
1 \text { session per week of } \\
30-60 \text { min }\end{array}$ & $6 \mathrm{~h}$ & $\begin{array}{l}\text { Minimal social } \\
\text { support }\end{array}$ \\
\hline Hastings and West (2009) & $\begin{array}{l}\text { To improve self-efficacy and } \\
\text { memory performance }\end{array}$ & $\begin{array}{l}\text { Multi-factorial training program centred on increasing } \\
\text { self-efficacy, including strategy training, class } \\
\text { discussions, homework reading and practice exercises } \\
\text { Self help participants used a manual containing the } \\
\text { same strategy training material and practice exercises }\end{array}$ & 6 sessions of $2 \mathrm{~h}$ & $12 \mathrm{~h}$ & Waiting list \\
\hline Klusmann et al. (2010) & $\begin{array}{l}\text { To increase cognitive } \\
\text { performance }\end{array}$ & $\begin{array}{l}\text { Computer course (EG1): creative, coordinative, and } \\
\text { memory tasks } \\
\text { Physical exercise course (EG2): aerobic endurance, } \\
\text { strength, and flexibility training }\end{array}$ & $\begin{array}{l}6 \text { months } \\
75 \text { session of } 90 \mathrm{~min}\end{array}$ & $112.5 \mathrm{~h}$ & No contact \\
\hline McDougall et al. (2010) & $\begin{array}{l}\text { To increase memory } \\
\text { self-efficacy }\end{array}$ & $\begin{array}{l}\text { Memory training based on cognitive behavioral model } \\
\text { of everyday memory derived from Bandura's } \\
\text { self-efficacy theory (SeniorWISE study) }\end{array}$ & $\begin{array}{l}8 \text { sessions and } 4 \text { booster } \\
\text { sessions }\end{array}$ & $18 \mathrm{~h}$ & $\begin{array}{l}\text { Health promotion } \\
\text { training }\end{array}$ \\
\hline Mozolic et al. (2011) & $\begin{array}{l}\text { To help people suppress } \\
\text { irrelevant auditory and visual } \\
\text { stimuli }\end{array}$ & $\begin{array}{l}\text { Individual training program focused on visual and } \\
\text { auditory selective attention }\end{array}$ & 8 sessions of $1 \mathrm{~h}$ per week & $8 \mathrm{~h}$ & Educational lecture \\
\hline Noice and Noice (2009) & $\begin{array}{l}\text { To improve cognitive function } \\
\text { and affective measures }\end{array}$ & $\begin{array}{l}\text { Offering a specific type of novel, stimulating, } \\
\text { multi-modal activity: acting course }\end{array}$ & $\begin{array}{l}8 \text { sessions of } 1 \mathrm{~h} \\
2 \text { sessions per week }\end{array}$ & $8 \mathrm{~h}$ & $\begin{array}{l}\text { Waiting list } \\
\text { Additional control } \\
\text { group (CG2): } \\
\text { singing course }\end{array}$ \\
\hline Richmond et al. (2011) & $\begin{array}{l}\text { To improve performance on } \\
\text { WM tasks and generalization } \\
\text { to untrained task }\end{array}$ & $\begin{array}{l}\text { Complex WM training using both a verbal and a spatial } \\
\text { WM tasks }\end{array}$ & $\begin{array}{l}4-5 \text { weeks } \\
5 \text { days per week } \\
20-30 \text { min per day }\end{array}$ & $12.5 \mathrm{~h}$ & Active control \\
\hline
\end{tabular}




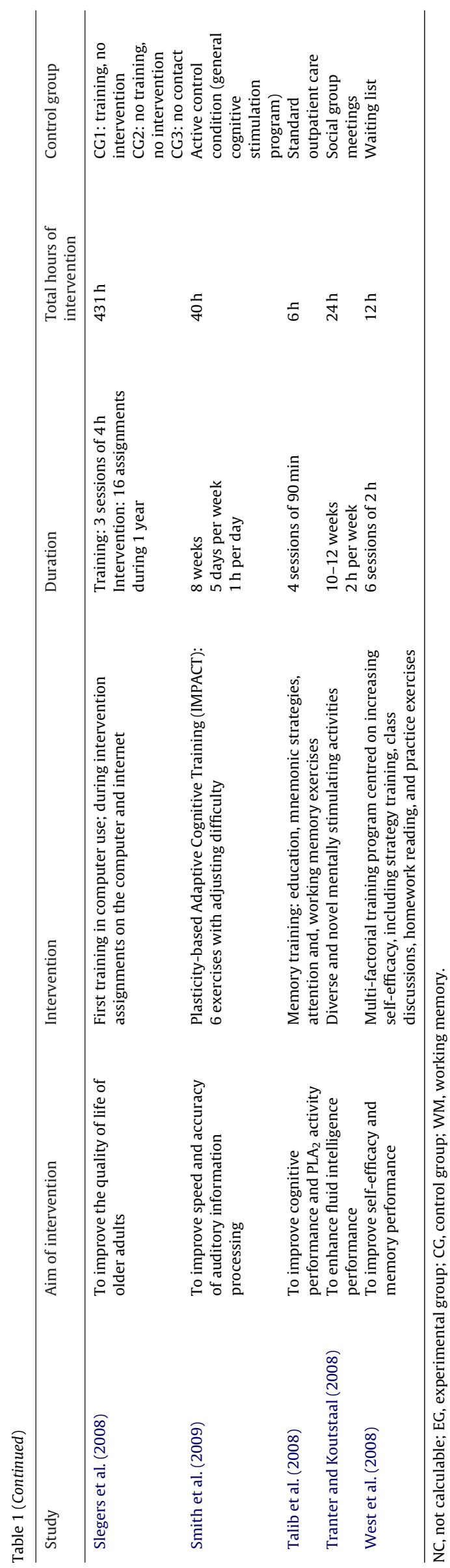

'cognitive stimulation' OR 'cognitive rehabilitation' OR 'brain training' OR 'memory training' OR 'mnemonic training'] AND ['healthy elderly' OR 'older adults' OR 'aging' OR 'mild cognitive impairment' OR ' $\mathrm{MCl}$ ']. This search was supplemented by manual search from the references of selected articles. In order to minimize the chance of missing relevant studies we extended the search terms used by Papp et al. (2009) and also used a combination of the search terms used by two earlier reviews (Martin et al., 2011; Papp et al., 2009).

The following inclusion criteria were used to identify studies as eligible: (1) randomized controlled trial or clinical study, (2) study population consisting of healthy older adults or people with MCI, (3) any type of cognitive intervention, and (4) use of objective and/or subjective outcome measures. Studies were excluded if the language was not English. Furthermore, papers based on the same study population were excluded. When more than one paper was found about a specific data set, only the main paper on the original study data was included for further analysis and quality assessment. If the original study was published before 2007 then the original study was also not included.

After the final selection, two reviewers (JR and MvB) extracted data independently and assessed the methodological quality of the studies using a standardized form of the Consort statement 2010 for randomized controlled trials (www.consort-statement.org) (Schulz et al., 2010). In case of discrepancies between the two raters, consensus was achieved after discussion. The methodological quality of the studies was indicated by the percentage of items of the Consort statement reported in the articles. Given the considerable heterogeneity of the interventions it was decided not to statistically pool the data of the studies in order to perform a quantitative meta-analysis.

\section{Results}

\subsection{Studies included}

In Fig. 1 the results of the selection process are shown. A total of thirty-five studies were selected for further analysis; twenty-seven RTCs and eight clinical studies. The clinical studies will be discussed separately. Of the twenty-seven RCTs, twenty-one intervention studies included a population of healthy older adults (Bailey et al., 2010; Basak et al., 2008; Berry et al., 2010; Borella et al., 2010; Bottiroli and Cavallini, 2009; Buiza et al., 2008; Buschkuehl et al., 2008; Carlson et al., 2008; Cavallini et al., 2010; Fairchild and Scogin, 2010; Hastings and West, 2009; Klusmann et al., 2010; McDougall et al., 2010; Mozolic et al., 2011; Noice and Noice, 2009; Richmond et al., 2011; Slegers et al., 2008; Smith et al., 2009; Talib et al., 2008; Tranter and Koutstaal, 2008; West et al., 2008) and six intervention studies included a population of people with MCI (Barnes et al., 2009; Jean et al., 2010b; Kinsella et al., 2009; Troyer et al., 2008; Tsolaki et al., 2011; Wagner et al., 2008). Tables 1 and 2 present the characteristics of the intervention programs (for healthy older adults population and $\mathrm{MCI}$ ) and Tables 3 and 4 present the characteristics of the included RCTs, including outcome measures and effects.

\subsection{Study characteristics}

The number of healthy older adults in the experimental groups varied from 13 (Buschkuehl et al., 2008) to 242 (Smith et al., 2009). The mean age of the study populations ranged from 63.5 (Cavallini et al., 2010) to 80.2 years (Noice and Noice, 2009). All studies were carried out in an experimental setting. A group-based intervention was used in ten studies (Bottiroli and Cavallini, 2009; Buiza et al., 2008; Buschkuehl et al., 2008; Carlson et al., 2008; Cavallini et al., 2010; Klusmann et al., 2010; McDougall et al., 2010; Noice 
Table 2

Intervention characteristics of studies in MCI population $(n=6)$.

\begin{tabular}{|c|c|c|c|c|c|}
\hline Study & Aim of intervention & Intervention & Duration & $\begin{array}{l}\text { Total hours of } \\
\text { intervention }\end{array}$ & Control group \\
\hline Barnes et al. (2009) & $\begin{array}{l}\text { To improve auditory } \\
\text { processing speed and accuracy }\end{array}$ & $\begin{array}{l}\text { Computer-based cognitive } \\
\text { training developed by Posit } \\
\text { Science Corporation }\end{array}$ & $\begin{array}{l}100 \mathrm{~min} / \text { day } \\
5 \text { days/week } \\
6 \text { weeks }\end{array}$ & $50 \mathrm{~h}$ & $\begin{array}{l}\text { More passive computer } \\
\text { activities }\end{array}$ \\
\hline Jean et al. (2010b) & $\begin{array}{l}\text { To re-learn face-name } \\
\text { associations }\end{array}$ & $\begin{array}{l}\text { Training in face-name } \\
\text { associations using both } \\
\text { errorless learning and spaced } \\
\text { retrieval paradigm and } \\
\text { psycho-educational sessions } \\
\text { on memory }\end{array}$ & $\begin{array}{l}6 \text { sessions of } \\
45 \mathrm{~min}\end{array}$ & $4.5 \mathrm{~h}$ & $\begin{array}{l}\text { Training in face-name } \\
\text { associations using errorless } \\
\text { learning paradigm and } \\
\text { psycho-educational sessions } \\
\text { on memory }\end{array}$ \\
\hline Kinsella et al. (2009) & $\begin{array}{l}\text { Memory rehabilitation, to } \\
\text { practice memory strategies for } \\
\text { everyday problems }\end{array}$ & $\begin{array}{l}\text { Practice in memory strategies } \\
\text { (internal and external), } \\
\text { strategies for improving } \\
\text { organisational and attentional } \\
\text { skills and general coping } \\
\text { strategies }\end{array}$ & $\begin{array}{l}1.5 \mathrm{~h} / \text { week } \\
5 \text { weeks }\end{array}$ & $7.5 \mathrm{~h}$ & Waiting list \\
\hline Troyer et al. (2008) & $\begin{array}{l}\text { Multidisciplinary group-based } \\
\text { intervention to change } \\
\text { everyday memory behavior }\end{array}$ & $\begin{array}{l}\text { Practice and application of } \\
\text { memory strategies and } \\
\text { education about lifestyle: } \\
\text { nutrition, recreation and } \\
\text { relaxation }\end{array}$ & $\begin{array}{l}10 \text { sessions of } \\
120 \mathrm{~min}\end{array}$ & $20 \mathrm{~h}$ & Waiting list \\
\hline Tsolaki et al. (2011) & $\begin{array}{l}\text { Holistic cognitive } \\
\text { rehabilitation program to cover } \\
\text { the needs and deficiencies of } \\
\text { patients with MCI }\end{array}$ & $\begin{array}{l}\text { Practice of attention and } \\
\text { parameters of executive } \\
\text { function; enhancement of } \\
\text { mental imagery, episodic, } \\
\text { semantic, autobiographical and } \\
\text { visual memory; } \\
\text { relaxation techniques }\end{array}$ & $\begin{array}{l}60 \text { sessions of } \\
90 \mathrm{~min} \\
3 \text { session/week }\end{array}$ & $90 \mathrm{~h}$ & Waiting list \\
\hline Wagner et al. (2008) & $\begin{array}{l}\text { To analyze everyday situations } \\
\text { with memory problem and } \\
\text { train specific strategies }\end{array}$ & $\begin{array}{l}\text { Practicing prospective memory } \\
\text { and structured processing of } \\
\text { new information related to } \\
\text { real-life situations }\end{array}$ & $\begin{array}{l}7 \text { sessions of } \\
90 \mathrm{~min}\end{array}$ & $10.5 \mathrm{~h}$ & No training \\
\hline
\end{tabular}

and Noice, 2009; Talib et al., 2008; West et al., 2008), the same number of studies used an individually based intervention (Bailey et al., 2010; Basak et al., 2008; Berry et al., 2010; Borella et al., 2010; Fairchild and Scogin, 2010; Mozolic et al., 2011; Richmond et al., 2011; Slegers et al., 2008; Smith et al., 2009; Tranter and Koutstaal, 2008) and one study used both (Hastings and West, 2009). Five studies included follow-up data, up till one year after the intervention (Borella et al., 2010; Buschkuehl et al., 2008; Hastings and West, 2009; Slegers et al., 2008; Smith et al., 2009).

The number of people with $\mathrm{MCI}$ in the intervention groups varied from 11 (Jean et al., 2010b) to 104 (Tsolaki et al., 2011). The mean age of the study populations ranged from 53.7 (Wagner et al., 2008) to 78 years (Kinsella et al., 2009). In four (out of six) studies, the interventions were carried out in a clinical setting (Barnes et al., 2009; Kinsella et al., 2009; Tsolaki et al., 2011; Wagner et al., 2008). A group-based intervention was used in four studies (Kinsella et al., 2009; Troyer et al., 2008; Tsolaki et al., 2011; Wagner et al., 2008), whereas two studies used an individually based intervention (Barnes et al., 2009; Jean et al., 2010b). In two studies the effectiveness of the intervention was not only assessed immediately after the intervention but also after three or four months (Kinsella et al., 2009; Troyer et al., 2008). In one study a follow-up assessment was planned (Wagner et al., 2008).

The total hours of intervention varied widely between studies, as can be seen in Tables 1 and 2. We performed a linear regression analysis to investigate whether the effectiveness of the intervention could be predicted by the total hours of intervention. The effectiveness of an intervention was calculated by dividing the number of significant outcome measures by the total number of outcome measures. We found no significant effect between total hours of intervention and intervention effect $\left(R^{2}: 0.016, p=0.54\right)$, indicating that in the included studies there was no dose response relationship between total hours of intervention and the effectiveness of the intervention.

\subsection{Description of interventions}

Table 1 shows the characteristics of the interventions that were performed in healthy older adults. Eleven studies aimed at improving memory performance; four studies addressed working memory by computerized training (Berry et al., 2010; Buschkuehl et al., 2008; Richmond et al., 2011) or training of the categorization span task (Borella et al., 2010); four studies provided training of the use of memory strategies (Bottiroli and Cavallini, 2009; Cavallini et al., 2010; Talib et al., 2008), accompanied with psycho-educational lessons (Fairchild and Scogin, 2010) and the other three studies aimed at improving memory self-efficacy by a multifactorial training program (Hastings and West, 2009; West et al., 2008) or a memory training program derived from Bandura's self-efficacy theory (McDougall et al., 2010). Six studies aimed at improving cognitive functioning in general by providing a computer course (Klusmann et al., 2010; Slegers et al., 2008), a plasticity-based adaptive cognitive training (Smith et al., 2009), a multifactorial cognitive training (Buiza et al., 2008), a community-based program (Carlson et al., 2008) or an acting course (Noice and Noice, 2009). Besides this, single studies aimed at improving learning abilities by training metacognitive skills (Bailey et al., 2010), executive functioning by a real-time strategy game (Basak et al., 2008), attentional skills by training a selective attention task (Mozolic et al., 2011) and fluid intelligence by novel stimulating activities (Tranter and Koutstaal, 2008). Ten studies used an active control condition, where the other eleven used a waiting list or no training control group. The duration of an intervention varied between 3 hourly sessions up till 180 sessions (Borella et al., 2010; Buiza et al., 2008).

Table 2 shows the characteristics of the interventions assessed in people with $\mathrm{MCI}$. Most interventions aimed at improving memory performance by training memory strategies (Jean et al., 2010b; Kinsella et al., 2009; Troyer et al., 2008; Tsolaki et al., 2011; Wagner et al., 2008), accompanied with psycho-education on memory 
Table 3

Study characteristics of intervention studies in healthy older adults $(n=21)$.

\begin{tabular}{|c|c|c|c|c|c|c|}
\hline Study & $\begin{array}{l}\text { Sample size } \\
\text { (EG/CG) }\end{array}$ & $\begin{array}{l}\text { Mean age } \\
\text { (year) }\end{array}$ & Intervention & Follow-up & Outcome measures of interest & $\begin{array}{l}\text { Significant effect for } \\
\text { experimental group }\end{array}$ \\
\hline Bailey et al. (2010) & $29 / 27$ & Range 60-89 & $\begin{array}{l}\text { Metacognitive training } \\
\text { at home }\end{array}$ & Post-intervention & $\begin{array}{l}\text { Self-paced memory task } \\
\text { Experimenter-paced memory task }\end{array}$ & $\begin{array}{l}+ \\
0\end{array}$ \\
\hline Basak et al. (2008) & $20 / 20$ & $69.1 / 70.0$ & $\begin{array}{l}\text { Strategy-based } \\
\text { real-time videogame }\end{array}$ & Post-intervention & $\begin{array}{l}\text { Operation span } \\
\text { Task switching } \\
\text { N-back task } \\
\text { Visual short-term memory } \\
\text { Raven's Advanced Progressive Matrices } \\
\text { Stopping task } \\
\text { Functional field of view } \\
\text { Attentional blink } \\
\text { Enumeration } \\
\text { Mental rotation }\end{array}$ & $\begin{array}{l}0 \\
+ \\
+ \\
+ \\
+ \\
0 \\
0 \\
0 \\
0 \\
+\end{array}$ \\
\hline Berry et al. (2010) & $15 / 15$ & 71.9 & $\begin{array}{l}\text { Perceptual } \\
\text { discrimination training }\end{array}$ & Post-intervention & $\begin{array}{l}\text { Trained perceptual task } \\
\text { Untrained perceptual task } \\
\text { WM/delayed recognition paradigm - NI } \\
\text { WM/delayed recognition paradigm - IS }\end{array}$ & $\begin{array}{l}+ \\
+ \\
+ \\
0\end{array}$ \\
\hline Borella et al. (2010) & $20 / 20$ & $69.0 / 69.2$ & Verbal WM training & $\begin{array}{l}\text { Post-intervention } \\
\text { and } 8 \text { months } \\
\text { follow up }\end{array}$ & $\begin{array}{l}\text { Visuospatial WM (dot matrix task) } \\
\text { Short-term memory (digit span) } \\
\text { Inhibition (stroop color task) } \\
\text { Processing speed (pattern comparison } \\
\text { task) } \\
\text { Fluid intelligence (Catell's Culture Fair) }\end{array}$ & $\begin{array}{l}+ \\
+ \\
+ \\
+(\text { also at } \mathrm{FU}) \\
+(\text { also at FU) }\end{array}$ \\
\hline $\begin{array}{l}\text { Bottiroli and Cavallini } \\
\text { (2009) }\end{array}$ & $21 / 23$ & $66.2 / 66.1$ & $\begin{array}{l}\text { Computer-based } \\
\text { memory training }\end{array}$ & Post-intervention & $\begin{array}{l}\text { Figure list recognition } \\
\text { Word list recognition } \\
\text { Face-name learning } \\
\text { Place-word learning } \\
\text { Paired associated recall }\end{array}$ & $\begin{array}{l}+ \\
+ \\
+ \\
+ \\
+\end{array}$ \\
\hline Buiza et al. (2008) & $85 / 68 / 85^{\mathrm{a}}$ & 74.4 & $\begin{array}{l}\text { Cognitive therapy } \\
\text { EG1: Cognitive } \\
\text { intervention and } \\
\text { well-being } \\
\text { EG2: cognitive therapy }\end{array}$ & Post-intervention & $\begin{array}{l}\text { Immediate memory } \\
\text { Recent logic execution memory } \\
\text { Short-term memory } \\
\text { Working memory } \\
\text { Learning potential } \\
\text { Visomanual coordination } \\
\text { Motor execution } \\
\text { Phonetic fluency } \\
\text { Capacity for abstraction } \\
\text { Praxis }\end{array}$ & $\begin{array}{l}+(\text { for EG1) } \\
0 \\
0 \\
+(\text { for EG1) } \\
+(\text { for EG1) } \\
0 \\
0 \\
0 \\
0 \\
+(\text { for EG1) }\end{array}$ \\
\hline $\begin{array}{l}\text { Buschkuehl et al. } \\
\text { (2008) }\end{array}$ & $13 / 19$ & 80.1 & $\begin{array}{l}\text { Computerized WM } \\
\text { training }\end{array}$ & $\begin{array}{l}\text { Post-intervention } \\
\text { and } 1 \text { year FU }\end{array}$ & $\begin{array}{l}\text { Visual free recall } \\
\text { Verbal free recall } \\
\text { Digit span } \\
\text { Block span }\end{array}$ & $\begin{array}{l}+ \\
0 \\
0 \\
+\end{array}$ \\
\hline Carlson et al. (2008) & $70 / 58$ & $70.1 / 68.4$ & $\begin{array}{l}\text { Community-based } \\
\text { program }\end{array}$ & At 4 and 8 months & $\begin{array}{l}\text { Word list memory } \\
\text { Trail Making Test } \\
\text { Rey-Osterrieth Complex figure test } \\
\text { Psychomotor speed }\end{array}$ & $\begin{array}{l}+ \\
+ \\
+ \\
0\end{array}$ \\
\hline Cavallini et al. (2010) & $27 / 24 / 29^{a}$ & $\begin{array}{l}65.8 / 63.5 \\
66.0\end{array}$ & $\begin{array}{l}\text { Memory training } \\
\text { EG1: training in } \\
\text { mnemonics } \\
\text { EG2: training in } \\
\text { mnemonics and } \\
\text { instructions }\end{array}$ & Post-intervention & $\begin{array}{l}\text { Associate learning (practiced task) } \\
\text { List learning (practiced task) } \\
\text { Text learning } \\
\text { Place learning } \\
\text { Name-face learning } \\
\text { Grocery list learning }\end{array}$ & $\begin{array}{l}+(\mathrm{EG} 1=\mathrm{EG} 2) \\
+(\mathrm{EG} 1=\mathrm{EG} 2) \\
+(\mathrm{EG} 2>\mathrm{EG} 1) \\
0 \\
0 \\
0\end{array}$ \\
\hline
\end{tabular}




\begin{tabular}{|c|c|c|c|c|c|c|}
\hline Fairchild and Scogin & $28 / 25$ & 72.4 & Memory enhancement & Post-intervention & Names and Faces task & + \\
\hline$(2010)$ & & & program & & Appointment Keeping task & 0 \\
\hline & & & & & Multifactorial Memory Questionnaire & + \\
\hline & & & & & Object Misplacement task & + \\
\hline & & & & & Target Complaints Methodology & + \\
\hline Hastings and West & $99 / 45 / 41^{a}$ & 70.9 & Memory training & Post-intervention & Memory Self-Efficacy Questionnaire & $+($ for EG1 at FU) \\
\hline$(2009)$ & & & EG1: group-based EG2: & (only performance & Metamemory in Adulthood ( 3 subscales) & \\
\hline & & & & measures) and 1 & -locus of control & $+(\mathrm{EG} 1$ and EG2, at FU) \\
\hline & & & & month FU & -anxiety & 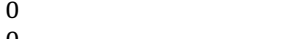 \\
\hline & & & & & -achievement & 0 \\
\hline & & & & & Name recall & $+(\mathrm{EG} 1$ and $\mathrm{EG} 2$, also at $\mathrm{FU})$ \\
\hline & & & & & Story recall & $+(\mathrm{EG} 1$ and EG2, also at FU) \\
\hline & & & & & Shopping list recall & 0 \\
\hline Klusmann et al. (2010) & $92 / 91 / 76^{\mathrm{a}}$ & 73.6 & Computer course (EG1) & Post-intervention & Rivermead Behavioral Memory Test & +(EG1 and EG2) \\
\hline & & & and physical exercise & & Free and Cued Selective Reminding Test & + (due to worsening in CG) \\
\hline & & & course (EG2) & & Verbal fluency & 0 \\
\hline & & & & & Stroop test & 0 \\
\hline & & & & & Trail Making Test & + (due to worsening in CG) \\
\hline & & & & & Subjective ratings of & \\
\hline & & & & & -memory & $+(\mathrm{EG} 1)$ \\
\hline & & & & & -concentration & $+($ EG1) \\
\hline & & & & & -flexibility & 0 \\
\hline & & & & & -physical health & $+(\mathrm{EG} 2)$ \\
\hline & & & & & -physical well-being & \\
\hline McDougall et al. (2010) & $135 / 130$ & 75 & Memory training & At $2,6,14$ and 26 & Mini-Mental State Exam & + (only at 2 months) \\
\hline & & & & months & Hopkins Verbal Learning Test - revised & 0 \\
\hline & & & & & Brief Visuospatial Memory Test & 0 \\
\hline & & & & & Rivermead Behavioral Memory Test & 0 \\
\hline & & & & & Direct Assessment of Functional Status & 0 \\
\hline & & & & & Memory Self-Efficacy Questionnaire & 0 \\
\hline & & & & & Spielberger State-Trait Anxiety Inventory & 0 \\
\hline & & & & & Centers for Epidemiologic Studies Scale & 0 \\
\hline & & & & & Metamemory in Adulthood & + \\
\hline Mozolic et al. (2011) & $33 / 33$ & 69.4 & Modality specific & Post-intervention & Selective attention task (cross-modal) & + \\
\hline & & & attention training & & Selective attention task (within-modality) & 0 \\
\hline & & & & & Multisensory integration task & + \\
\hline & & & & & Symbol Digit Modalities Test & + \\
\hline & & & & & Walk and talk paradigm & + \\
\hline & & & & & Letter $\mathrm{n}$-back test & 0 \\
\hline & & & & & Stroop test & 0 \\
\hline & & & & & Trail Making Test & 0 \\
\hline & & & & & Hopkins verbal learning test & 0 \\
\hline & & & & & Profile of Mood States & 0 \\
\hline & & & & & Health status Questionnaire & 0 \\
\hline Noice and Noice (2009) & $42 / 40 / 40^{\mathrm{b}}$ & $80.2 / 82.7 / 81.6$ & Multi-modal activities & Post-intervention & Word list recall & + \\
\hline & & & in college acting classes & & Delayed word list recall & + \\
\hline & & & EG: acting course & & Category Fluency & 0 \\
\hline & & & CG1: no intervention & & Digit Span & + (only EG compared to \\
\hline & & & CG2: singing course & & Story Recall Task & CG1) \\
\hline & & & & & Problem Solving & + \\
\hline & & & & & Self-reported Personal Growth & $\begin{array}{l}0 \text { (improved in EG and } \\
\text { CG2) }\end{array}$ \\
\hline & & & & & Memory Controllability Inventory & 0 \\
\hline & & & & & Lifestyle Activities Questionnaire & 0 \\
\hline
\end{tabular}




\begin{tabular}{|c|c|c|c|c|c|c|}
\hline Study & $\begin{array}{l}\text { Sample size } \\
\text { (EG/CG) }\end{array}$ & $\begin{array}{l}\text { Mean age } \\
\text { (year) }\end{array}$ & Intervention & Follow-up & Outcome measures of interest & $\begin{array}{l}\text { Significant effect for } \\
\text { experimental group }\end{array}$ \\
\hline \multirow[t]{10}{*}{ Richmond et al. (2011) } & $21 / 19$ & 66 & Verbal and spatial WM training & Post-intervention & Reading span & + \\
\hline & & & & & Digit span forward & 0 \\
\hline & & & & & Digit span backward & 0 \\
\hline & & & & & Raven's Advanced Progressive Matrices & 0 \\
\hline & & & & & Test of everyday attention & 0 \\
\hline & & & & & CVLT: total correct & 0 \\
\hline & & & & & CVLT: repetitions & + \\
\hline & & & & & CVLT: intrusions & 0 \\
\hline & & & & & Self-reports: memory & + \\
\hline & & & & & Self-reports: attention & + \\
\hline \multirow{14}{*}{ Slegers et al. $(2008)^{\mathrm{f}}$} & $60 / 49 / 55 / 40^{c}$ & Range 64-75 & Computer training and Internet & Post-intervention and 12 months & Short-Form Health Survey (SF-36) & 0 \\
\hline & & & Usage & $\mathrm{FU}$ & Loneliness questionnaire & 0 \\
\hline & & & EG: training and intervention & & Symptom Check List - 90 & 0 \\
\hline & & & CG1: training, no intervention & & Development and activity (self-report) & 0 \\
\hline & & & CG2: no training, no intervention & & Instrumental Activities of Daily Living & 0 \\
\hline & & & CG3: no contact & & Belief in External Control Scale & 0 \\
\hline & & & & & Mastery Scale & 0 \\
\hline & & & & & Computer use & 0 \\
\hline & & & & & Visual verbal learning test & 0 \\
\hline & & & & & Motor choice reaction time test & 0 \\
\hline & & & & & Letter digit substitution test & 0 \\
\hline & & & & & Concept shifting test & 0 \\
\hline & & & & & Stroop color word test & 0 \\
\hline & & & & & Cognitive Failure Questionnaire & 0 \\
\hline \multirow{7}{*}{ Smith et al. (2009) } & $242 / 245$ & $75.6 / 75.0$ & Computerized cognitive training & Post-intervention and 3 months FU & RBANS (auditory memory and attention) & + \\
\hline & & & & & Rey Auditory Verbal Learning Test & $+($ also at $\mathrm{FU})$ \\
\hline & & & & & Rivermead Behavioral Memory Test & 0 \\
\hline & & & & & Digit span backwards test & + \\
\hline & & & & & Letter-number sequencing & $+($ also at FU) \\
\hline & & & & & Processing speed & $+($ also at FU) \\
\hline & & & & & Cognitive Self-Report Questionnaire & + \\
\hline \multirow[t]{5}{*}{ Talib et al. (2008) } & $11 / 12$ & $67.8 / 67.3$ & Memory training & Post-intervention & Prose recall & + \\
\hline & & & & & List recall & 0 \\
\hline & & & & & WAIS digit symbol & + \\
\hline & & & & & Number of underlined words in short text & 0 \\
\hline & & & & & Categorization measure & + \\
\hline \multirow{2}{*}{$\begin{array}{l}\text { Tranter and Koutstaal } \\
\text { (2008) }\end{array}$} & $22 / 22$ & 67.8 & Mentally stimulating activities & Post-intervention & Catell's Culture Fair (fluid intelligence) & + \\
\hline & & & & & WAIS-R blocks (Spatial perceptual test) & + \\
\hline \multirow[t]{10}{*}{ West et al. (2008) } & $42 / 42$ & 69.9 & Group-based memory training & Post-intervention at week 6 and & Memory Self-Efficacy Questionnaire & + \\
\hline & & & & week 9 & Metamemory in Adulthood ( 3 subscales) & \\
\hline & & & & & -locus of control & + \\
\hline & & & & & -anxiety & 0 \\
\hline & & & & & -achievement & 0 \\
\hline & & & & & Name recall & + \\
\hline & & & & & Story recall & + \\
\hline & & & & & Shopping list recall & 0 \\
\hline & & & & & Digit symbol substitution test & 0 \\
\hline & & & & & Strategy checklist-effective strategy use & + \\
\hline
\end{tabular}

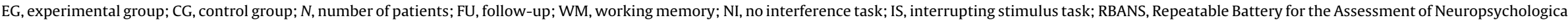
Status; CVLT, California Verbal Learning Test.

a Two experimental groups.

b Two control groups.

c Three control groups.

d +, positive effect for experimental group; 0 , no difference between groups; -, negative effect for experimental group.

e Subjective measures reported in Klusmann et al. (2011).

f Objective outcome measures reported in Slegers et al. (2009). 
Table 4

Study characteristics of intervention studies in $\mathrm{MCI}$ population $(n=6)$.

\begin{tabular}{|c|c|c|c|c|c|c|}
\hline Study & $\begin{array}{l}\text { Sample size } \\
(\mathrm{EG} / \mathrm{CG})\end{array}$ & $\begin{array}{l}\text { Mean age } \\
\text { (year) }\end{array}$ & Intervention & Follow-up & Outcome measures of interest & $\begin{array}{l}\text { Significant effect for } \\
\text { experimental group }\end{array}$ \\
\hline Barnes et al. (2009) & $22 / 25$ & 74 & $\begin{array}{l}\text { Computer-based } \\
\text { auditory } \\
\text { processing speed } \\
\text { training }\end{array}$ & Post-intervention & $\begin{array}{l}\text { RBANS } \\
\text { California verbal learning test } \\
\text { Boston naming test } \\
\text { Trial making test } \\
\text { Verbal fluency } \\
\text { Design fluency } \\
\text { Spatial span }\end{array}$ & $\begin{array}{l}0 \\
0 \\
0 \\
0 \\
0 \\
0 \\
0\end{array}$ \\
\hline Jean et al. (2010b) & $11 / 11$ & 68.5 & $\begin{array}{l}\text { Training in } \\
\text { face-name } \\
\text { associations }\end{array}$ & $\begin{array}{l}\text { Post-intervention } \\
\text { at } 1 \text { and } 4 \text { weeks }\end{array}$ & $\begin{array}{l}\text { Face-name associations } \\
\text { California verbal learning test } \\
\text { Dementia Rating Scale } \\
\text { Mini Mental State Examination } \\
\text { Rivermead Behavioral Memory Test } \\
\text { Self-esteem scale } \\
\text { Multifactorial Memory Questionnaire }\end{array}$ & $\begin{array}{l}0^{\mathrm{b}} \\
0 \\
0 \\
0 \\
0 \\
0 \\
0^{\mathrm{b}}\end{array}$ \\
\hline Kinsella et al. (2009) & $22 / 22$ & 78 & $\begin{array}{l}\text { Strategy training } \\
\text { (memory, } \\
\text { attention, and } \\
\text { organisational } \\
\text { skills) }\end{array}$ & $\begin{array}{l}\text { Post-intervention } \\
\text { at } 2 \text { weeks and } 4 \\
\text { months }\end{array}$ & $\begin{array}{l}\text { Prospective memory } \\
\text { MMQ-ability } \\
\text { MMQ-strategy } \\
\text { MMQ-contentment } \\
\text { Strategy knowledge repertoire }\end{array}$ & $\begin{array}{l}+ \\
0 \\
0 \\
0 \\
+\end{array}$ \\
\hline Troyer et al. (2008) & $24 / 24$ & 75.4 & $\begin{array}{l}\text { Memory strategies } \\
\text { training and } \\
\text { lifestyle education }\end{array}$ & $\begin{array}{l}\text { Post-intervention } \\
\text { and } 3 \text { months }\end{array}$ & $\begin{array}{l}\text { Memory Toolbox } \\
\text { Multifactorial Memory Questionnaire } \\
\text { Impact rating scale } \\
\text { Lifestyle importance } \\
\text { Name recall } \\
\text { Number recall } \\
\text { Wordlist recall }\end{array}$ & $\begin{array}{l}+ \\
0 \\
0 \\
0 \\
0 \\
0 \\
0\end{array}$ \\
\hline Tsolaki et al. (2011) & $104 / 72$ & 67 & $\begin{array}{l}\text { Cognitive } \\
\text { rehabilitation } \\
\text { program }\end{array}$ & Post-intervention & $\begin{array}{l}\text { Mini Mental State Examination } \\
\text { Montreal Cognitive Assessment } \\
\text { Functional Cognitive Assessment Scale } \\
\text { MoCA (verbal memory) } \\
\text { Rey-Österrieth Complex Figure Test } \\
\text { MoCA (Clock drawing) } \\
\text { Functional Rating Scale of Symptoms } \\
\text { of Dementia }\end{array}$ & $\begin{array}{l}+ \\
+ \\
+ \\
+ \\
+ \\
+ \\
+\end{array}$ \\
\hline Wagner et al. (2008) & $33 / 40$ & 53.7 & $\begin{array}{l}\text { Behavioral analysis } \\
\text { and memory } \\
\text { strategy training }\end{array}$ & $\begin{array}{l}\text { Post-intervention } \\
\text { and follow up } \\
\text { planned }\end{array}$ & $\begin{array}{l}\text { Appointment test } \\
\text { Logical memory I } \\
\text { Logical memory II } \\
\text { Memory assessment clinics } \\
\text { questionnaire }\end{array}$ & $\begin{array}{l}+ \\
0 \\
+ \\
+\end{array}$ \\
\hline
\end{tabular}

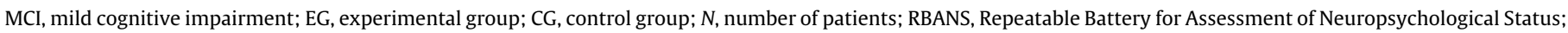
MMQ, Multifactorial Memory Questionnaire; MoCA, Montreal Cognitive Assessment.

a + , positive effect for experimental group; 0 , no difference between groups; -, negative effect for experimental group.

b Improved in both groups.

(Jean et al., 2010b), lifestyle (Troyer et al., 2008), or practice of attentional skills (Kinsella et al., 2009; Tsolaki et al., 2011). One study aimed at improving processing speed by using a computer-based cognitive training program (Barnes et al., 2009). Two studies used an active control condition, where the other four used a waiting list or no training control group. The duration of an intervention varied between 5 and 20 weeks (Kinsella et al., 2009; Tsolaki et al., 2011).

\subsection{Outcome measures and effects}

In the twenty-one RCTs in healthy older adults included in our analysis, the most commonly used outcome measure was objective memory performance (twenty studies) (Table 3). In seventeen studies, memory performance was significantly improved after the intervention. Significant differences were observed on the following tasks; self-paced memory task (Bailey et al., 2010), working memory tasks (Basak et al., 2008; Berry et al., 2010; Borella et al., 2010; Buiza et al., 2008; Buschkuehl et al., 2008; Richmond et al., 2011; Smith et al., 2009; Talib et al., 2008), recognition task (Bottiroli and Cavallini, 2009), face-name learning tasks (Bottiroli and Cavallini, 2009; Fairchild and Scogin, 2010), immediate memory and learning potential (Buiza et al., 2008), word list recall (Carlson et al., 2008; Cavallini et al., 2010; Noice and Noice, 2009), name recall (Hastings and West, 2009; West et al., 2008), story/text recall (Cavallini et al., 2010; Hastings and West, 2009; Noice and Noice, 2009; Talib et al., 2008; West et al., 2008), Rivermead Behavioral Memory Test (Klusmann et al., 2010), Repeatable Battery for the Assessment of Neuropsychological Status (Smith et al., 2009), Rey Auditory Verbal Learning Test (Smith et al., 2009), memory strategy use (Talib et al., 2008; West et al., 2008). In eight studies, measures of executive functioning were included, of which five studies showed significant effects on the following tasks; task switching (Basak et al., 2008), Stroop Color Word Task (Borella et al., 2010), Trail Making Test (Carlson et al., 2008), Rey-Österrieth Complex Figure Test (Carlson et al., 2008), Symbol Digit Modalities Test (Mozolic et al., 2011), walk and talk paradigm (Mozolic et al., 2011), fluency and problem solving (Noice and Noice, 2009). In three studies, significant improvement on (fluid) intelligence test were observed; Catell's Culture Fair (Bottiroli and Cavallini, 2009; Tranter and Koutstaal, 2008), Raven's Advanced Progressive Matrices (Basak et al., 2008). In two studies, significant improvement on attentional tasks were observed; selective attention task, multisensory integration task (Mozolic et al., 2011), Repeatable Battery for Assessment of Neuropsychological Status (Smith et al., 2009). In two studies, significant improvement in speed of processing was observed (Borella et al., 2010; Smith et al., 2009). In one study a measure of general cognitive functioning (Mini Mental 
State Examination) was included as an outcome measure and significantly improved by the intervention (McDougall et al., 2010). Subjective measures of cognitive performance were included in five studies. Significant effects were observed for the Multifactorial Memory Questionnaire (Fairchild and Scogin, 2010), Object Misplacement task (Fairchild and Scogin, 2010), Memory SelfEfficacy Questionnaire (Hastings and West, 2009; West et al., 2008), Metamemory in Adulthood (Hastings and West, 2009; McDougall et al., 2010; West et al., 2008), and Cognitive Self-Report Questionnaire (Smith et al., 2009). In two studies, measures of daily functioning (Direct Assessment of Functional Status (McDougall et al., 2010) and Instrumental Activities of Daily Living (Slegers et al., 2008)) were included, but no significant effect were observed.

All six RCTs in the MCI population included in our analysis used objective memory performance as an outcome measure: in four studies memory performance significantly improved after the intervention (Table 4). Significant improvements were observed on the following tasks; prospective memory (Kinsella et al., 2009), memory strategy knowledge (Kinsella et al., 2009; Troyer et al., 2008), verbal memory (Montreal Cognitive Assessment) (Tsolaki et al., 2011), appointment test (Wagner et al., 2008) and logical memory (Wagner et al., 2008). In two studies measures of executive functioning were included; the functional cognitive assessment scale was significantly improved by the intervention in one study (Tsolaki et al., 2011). In three studies, a measure of general cognitive functioning was included. In only one study general cognitive performance, measured with the Mini Mental State Examination and the Montreal Cognitive Assessment was significantly improved by the intervention (Tsolaki et al., 2011). In three studies, a subjective measure of cognitive performance was included, the Multifactorial Memory Questionnaire, although no significant effects were found on this scale. In one study a significant improvement on a measure of daily functioning (Functional Rating Scale of Symptoms of Dementia) was observed (Tsolaki et al., 2011).

\subsection{Methodological quality of study}

The methodological quality of the twenty-seven RCTs was assessed. The percentage of the Consort items reported in the included studies ranged from $16 \%$ to $73 \%$, with an average of $44 \%$ (Table 5). The study of Smith et al. (2009) had the highest methodological quality (73\%), while the study of Wagner et al. (2008) had the lowest quality (16\%). The Consort statement can be divided into seven categories: 'title/abstract'; 'introduction'; 'methods-trial'; methods-randomization'; 'results'; 'discussion'; and 'other information.' In five of these categories ('title/abstract,' 'methods-trial,' 'methods-randomization,' 'results,' and 'other information') less than $50 \%$ of the items was reported.

\subsection{Non-randomized controlled trials}

Eight non-RCTs were included; three clinical studies in healthy older adults (Ackerman et al., 2010; Li et al., 2008; Schmiedek et al., 2010) and five clinical studies in people with MCI (Greenaway et al., 2008; Hampstead et al., 2008; Joosten-Weyn Banningh et al., 2008; Londos et al., 2008; Ozgis et al., 2009).

In healthy older adults, one study aimed at improving working memory performance by computerized training. The working memory training showed improvements on practiced and near transfer tasks but no effects on far transfer tasks (Li et al., 2008). Two studies aimed at improving cognitive functioning in general. Schmiedek et al. (2010) provided an internet-based training environment including tasks of perceptual speed, episodic memory, and working memory. They used only self-report evaluation reports as outcome measures. Ackerman et al. (2010) provided a brain training environment including training sessions with the
Nintendo Wii and reading sessions which showed practice-related improvement but no significant transfer effects.

In people with $\mathrm{MCI}$, two studies focused on improving adaptive behavior and functional ability. Greenaway et al. (2008) showed improvement in functional ability by the use of a 'memory support system' and Joosten-Weyn Banningh et al. (2008) provided cognitive behavioral group therapy which resulted in increased acceptance and marital satisfaction in people with $\mathrm{MCI}$ and increased awareness in their caregivers. The results of two studies focusing on memory improvement (by memory strategy training or spaced retrieval memory training) showed practicerelated effects (Hampstead et al., 2008; Ozgis et al., 2009). The study of Londos et al. (2008) examined the effect of an established rehabilitation program designed to improve cognitive performance, occupational performance, and quality of life. The results showed improvements in cognitive processing speed, occupational performance, and some domains of quality of life (Londos et al., 2008).

\section{Discussion}

This systematic review, evaluating the effectiveness of cognitive interventions in healthy older adults and people with $\mathrm{MCI}$, showed that cognitive interventions can be effective in improving various aspects of objective cognitive functioning; memory performance, executive functioning, processing speed, attention, fluid intelligence, and subjective cognitive performance. A critical comparison between different intervention studies is difficult because of the heterogeneity of the intervention programs and the chosen outcome measures. Most intervention studies used memory performance as the primary outcome measure, but only few studies used similar tests to measure memory functioning which frustrated a more quantitative meta-analysis on these studies. Different intervention programs proved to be effective in improving either objective or subjective memory performance; training of memory strategies (Bottiroli and Cavallini, 2009; Cavallini et al., 2010; Talib et al., 2008; Wagner et al., 2008), accompanied with practice of attentional skills (Kinsella et al., 2009; Tsolaki et al., 2011), psycho-educational lessons on memory and/or lifestyle (Fairchild and Scogin, 2010; Troyer et al., 2008); computerized training of working memory task (Berry et al., 2010; Borella et al., 2010; Buschkuehl et al., 2008; Richmond et al., 2011); and training programs focusing on memory self-efficacy or metacognition (Hastings and West, 2009; McDougall et al., 2010; West et al., 2008). Executive functioning was mostly included as a secondary outcome measure, and only two intervention programs aimed directly at improving executive functioning (Basak et al., 2008; Carlson et al., 2008).

In addition to the heterogeneity of the included intervention studies, the methodological quality of the studies differed vastly: only between $16 \%$ and $73 \%$ of the quality criteria items were addressed in the studies. When assessing studies with a high quality rating ( $>60 \%$ of the Consort quality criteria), we observed both positive and negative results. The study of Smith et al. (2009) showed that computerized cognitive training led to improvement of performance generalizing to untrained measures of memory and attention and subjective everyday functioning. The study of Klusmann et al. (2010) showed that a 6-month computer course had a positive affect on memory performance (measured with the Rivermead Behavioral Memory Test) in healthy older adults. However, the same improvement was achieved with a 6-month physical exercise course (Klusmann et al., 2010). In people with $\mathrm{MCI}$, a computer-based auditory processing speed training showed no improvements on memory, executive, or general cognitive performance (Barnes et al., 2009). However, a 5-week memory rehabilitation program focusing on practicing memory strategies 
Table 5

Quality assessment of included studies using the Consort statement 2010.

\begin{tabular}{|c|c|c|c|c|c|c|c|c|}
\hline & $\begin{array}{l}\text { Title, abstract } \\
(\max .2)\end{array}$ & $\begin{array}{l}\text { Introduction } \\
(\max .2)\end{array}$ & $\begin{array}{l}\text { Methods-trial } \\
\text { (max. 9) }\end{array}$ & $\begin{array}{l}\text { Methods-randomization } \\
(\max .8)\end{array}$ & $\begin{array}{l}\text { Results } \\
(\max .10)\end{array}$ & $\begin{array}{l}\text { Discussion } \\
(\max .3)\end{array}$ & \multirow{2}{*}{$\begin{array}{l}\text { Other information } \\
(\max .3)\end{array}$} & \multirow{2}{*}{$\begin{array}{l}\text { Total }(\%) \text { score } \\
(\max .37) \\
24(65 \%)\end{array}$} \\
\hline Barnes et al. (2009) & 2 & 2 & 5 & 5 & 5 & 3 & & \\
\hline Jean et al. (2010a) & 1 & 2 & 5 & 4 & 5 & 2 & 1 & $20(54 \%)$ \\
\hline Kinsella et al. (2009) & 2 & 2 & 5 & 5 & 6 & 3 & 1 & $24(65 \%)$ \\
\hline Troyer et al. (2008) & 1 & 2 & 4 & 4 & 6 & 2 & 0 & $19(51 \%)$ \\
\hline Tsolaki et al. (2011) & 1 & 2 & 2 & 2 & 2 & 1 & 0 & $10(27 \%)$ \\
\hline Wagner et al. (2008) & 0 & 2 & 3 & 0 & 1 & 0 & 0 & $6(16 \%)$ \\
\hline Bailey et al. (2010) & 0 & 1 & 4 & 1 & 3 & 3 & 1 & $13(35 \%)$ \\
\hline Basak et al. (2008) & 0 & 2 & 5 & 1 & 6 & 3 & 1 & $18(49 \%)$ \\
\hline Berry et al. (2010) & 0 & 1 & 4 & 2 & 4 & 1 & 1 & $13(35 \%)$ \\
\hline Borella et al. (2010) & 0 & 2 & 4 & 2 & 3 & 3 & 0 & $14(38 \%)$ \\
\hline $\begin{array}{l}\text { Bottiroli and Cavallini } \\
\text { (2009) }\end{array}$ & 1 & 1 & 4 & 2 & 4 & 1 & 0 & $13(35 \%)$ \\
\hline Buiza et al. (2008) & 1 & 1 & 3 & 0 & 0 & 2 & 1 & $8(22 \%)$ \\
\hline $\begin{array}{l}\text { Buschkuehl et al. } \\
\text { (2008) }\end{array}$ & 0 & 2 & 3 & 1 & 4 & 3 & 1 & $14(38 \%)$ \\
\hline Carlson et al. (2008) & 1 & 2 & 5 & 2 & 5 & 3 & 1 & $19(51 \%)$ \\
\hline Cavallini et al. (2010) & 0 & 1 & 3 & 2 & 2 & 2 & 1 & $11(30 \%)$ \\
\hline $\begin{array}{l}\text { Fairchild and Scogin } \\
\text { (2010) }\end{array}$ & 0 & 2 & 1 & 3 & 6 & 3 & 1 & $16(43 \%)$ \\
\hline $\begin{array}{l}\text { Hastings and West } \\
\text { (2009) }\end{array}$ & 0 & 2 & 4 & 1 & 3 & 3 & 1 & $14(38 \%)$ \\
\hline Klusmann et al. (2010) & 2 & 2 & 6 & 6 & 6 & 3 & 1 & $26(70 \%)$ \\
\hline McDougall et al. (2010) & 0 & 2 & 4 & 3 & 5 & 2 & 2 & $18(49 \%)$ \\
\hline Mozolic et al. (2011) & 1 & 2 & 4 & 4 & 4 & 3 & 1 & $19(51 \%)$ \\
\hline Noice and Noice (2009) & 0 & 2 & 4 & 2 & 6 & 2 & 1 & $17(46 \%)$ \\
\hline Richmond et al. (2011) & 0 & 2 & 4 & 2 & 3 & 3 & 1 & $15(41 \%)$ \\
\hline Slegers et al. (2008) & 1 & 2 & 5 & 4 & 5 & 3 & 1 & $21(57 \%)$ \\
\hline Smith et al. (2009) & 1 & 2 & 5 & 7 & 8 & 3 & 1 & $27(73 \%)$ \\
\hline Talib et al. (2008) & 0 & 2 & 3 & 1 & 3 & 1 & 1 & $11(30 \%)$ \\
\hline $\begin{array}{l}\text { Tranter and Koutstaal } \\
\text { (2008) }\end{array}$ & 0 & 2 & 3 & 1 & 5 & 3 & 1 & $15(41 \%)$ \\
\hline West et al. (2008) & 0 & 2 & 2 & 1 & 3 & 3 & 1 & $12(32 \%)$ \\
\hline Total for category (\%) 5 & $8 \%)$ & 104( & $(43 \%)$ & $1 \%)$ & $(42 \%)$ & 24 & $0 \%)$ & $44 \%$ \\
\hline
\end{tabular}

did show improvements on prospective memory task and strategy knowledge repertoire (Kinsella et al., 2009).

Another aspect of methodological quality, not specifically addressed in the Consort Statement items, is whether the control group received an active control intervention or no intervention. With an active control condition the effects of, for example, social attention as part of group meetings can be controlled for. When looking at the RCTs in the healthy older adults, ten RCTs included an active control condition. These studies did show an effect on measures of cognitive functioning, more specifically executive functioning, speed, attention, and subjective memory functioning (Borella et al., 2010; Buschkuehl et al., 2008; Fairchild and Scogin, 2010; McDougall et al., 2010; Mozolic et al., 2011; Noice and Noice, 2009; Richmond et al., 2011; Slegers et al., 2008; Smith et al., 2009; Tranter and Koutstaal, 2008). In the MCI population, two studies included an active control group. The interventions executed in these two studies did not show any significant effect (Barnes et al., 2009; Jean et al., 2010b). In conclusion, evaluating the results of intervention studies with an active control condition, it may be concluded that cognitive interventions can have a positive effect on various aspects of both objective and subjective cognitive functioning in healthy older adults, but not in people with MCI.

An important question that was raised in earlier reviews is whether observed training effects on various aspects of cognitive functioning generalize to untrained tasks or overall cognitive functioning, or lead to functional improvement in daily life situations. A number of studies specifically addressed the question of generalization to untrained task or to subjective experience of cognitive functioning (Berry et al., 2010; Borella et al., 2010; Bottiroli and Cavallini, 2009; Buschkuehl et al., 2008; Fairchild and Scogin, 2010; Richmond et al., 2011; Smith et al., 2009). Activities of Daily Living (ADL) measures were included in three intervention studies and a significant effect on ADL was observed in one study (Smith et al., 2009). From these data it can be concluded that there is very little evidence for generalization effects to overall cognitive functioning and daily life situations. The issue whether the effects of cognitive interventions generalize to improvement in everyday life activities still needs to be addressed more explicitly in future research.

Another important question is whether there is evidence of the rooting of training effect after the training period has ended. Follow-up data were available in seven out of twenty-six RCTs. They showed that positive effects on memory strategy knowledge remained after 3/4 months (Kinsella et al., 2009; Troyer et al., 2008), positive effects on memory self-efficacy and recall tasks preserved after 1 month (Hastings and West, 2009), positive effects on memory and speed preserved after 3 months (Smith et al., 2009), and positive effects on speed and fluid intelligence preserved after 8 months (Borella et al., 2010). Two studies including a 1-year follow up did not find any significant effects (Buschkuehl et al., 2008; Slegers et al., 2008). From these data it can be concluded that training effects can be preserved at least for a couple of months.

In comparison to the earlier reviews of Papp et al. (2009), Martin et al. (2011) and Tardif and Simard (2011), more intervention studies were included in this review. This could be the results of using more elaborated search terms or an increase in studies investigating the effect of cognitive interventions in the last few years. However, our conclusions are in line with the conclusions of these earlier reviews (Martin et al., 2011; Papp et al., 2009; Tardif and Simard, 2011). A strength of this study, in comparison with earlier reviews, is the methodological quality rating we performed according to the Consort Statement 2010 for RCTs. The methodological quality of the twenty-seven RCTs differed considerably. Taking into account that some items (such as blinding, serious harms, and interim analysis) are less applicable for non-pharmacological 
interventions, it seems clear that substantial improvement in terms of study quality can still be made in future intervention studies. In this review we included intervention studies from both healthy older adults and MCI populations. Although a clear differentiation between these two populations can be made with regard to normal versus pathological aging, the intervention programs applied cannot be clearly differentiated and the question whether people with $\mathrm{MCI}$ benefit from other intervention programs than healthy older adults still needs to be answered. A limitation of this review is that due to the heterogeneity of the intervention programs and outcome measures, we were not able to conduct a quantitative meta-analysis. Besides this, the selected search terms and possible publication bias are two aspects which could have influenced the results our review.

\subsection{Conclusions}

The results show evidence that cognitive training can be effective in improving various aspects of objective cognitive functioning; memory performance, executive functioning, processing speed, attention, fluid intelligence, and subjective cognitive performance. A critical comparison between different intervention studies is difficult because of the heterogeneity of the intervention programs and the chosen outcome measures. In addition to the heterogeneity of the included intervention studies, the methodological quality of the studies differed widely. The issue whether the effects of cognitive interventions generalize to improvement in everyday life activities is still unresolved and needs to be addressed more explicitly in future research. For future research, inclusion of a core set of outcome measures would be necessary to compare the effectiveness of different cognitive intervention programs. Both objective and subjective outcome measures for specific cognitive domains (e.g. memory, executive functioning) and ecological valid measures that show improvements in daily cognitive functioning should be part of this core set of outcome measures. Besides this, the methodological quality of future intervention studies should be improved by specifically addressing the quality control items contained in the Consort criteria. In particular, the description of trial design and randomization should be reporting more accurately and follow up assessments should be included.

\section{Source of funding}

This study was funded by the National Initiative Brain \& Cognition (NIBC) and the Netherlands Organization for Scientific Research (NWO).

\section{Conflict of interest}

We declare that there are no conflicts of interest.

\section{References}

Ackerman, P.L., Kanfer, R., Calderwood, C., 2010. Use it or lose it? Wii brain exercise practice and reading for domain knowledge. Psychology and Aging 25 (4), 753-766.

Bailey, H., Dunlosky, J., Hertzog, C., 2010. Metacognitive training at home: does it improve older adults' learning? Gerontology 56 (4), 414-420.

Barnes, D.E., et al., 2009. Computer-based cognitive training for mild cognitive impairment: results from a pilot randomized, controlled trial. Alzheimer Disease and Associated Disorders 23 (3), 205-210.

Basak, C., et al., 2008. Can training in a real-time strategy video game attenuate cognitive decline in older adults? Psychology and Aging 23 (4), 765-777.

Berry, A.S., et al., 2010. The influence of perceptual training on working memory in older adults. PLoS One 5 (7), e11537.

Borella, E., et al., 2010. Working memory training in older adults: evidence of transfer and maintenance effects. Psychology and Aging 25 (4), 767-778.

Bottiroli, S., Cavallini, E., 2009. Can computer familiarity regulate the benefits of computer-based memory training in normal aging? A study with an Italian sample of older adults. Neuropsychology, Development, and Cognition. Section B, Aging, Neuropsychology and Cognition 16 (4), 401-418.

Buiza, C., et al., 2008. A randomized, two-year study of the efficacy of cognitive intervention on elderly people: the Donostia Longitudinal Study. International Journal of Geriatric Psychiatry 23 (1), 85-94.

Buschkuehl, M., et al., 2008. Impact of working memory training on memory performance in old-old adults. Psychology and Aging 23 (4), 743-753.

Carlson, M.C., et al., 2008. Exploring the effects of an everyday activity program on executive function and memory in older adults: experience corps. Gerontologist 48 (6), 793-801.

Cavallini, E., et al., 2010. Promoting transfer in memory training for older adults. Aging Clinical and Experimental Research 22 (4), 314-323.

CBS, 2009. Health and Care in Figures 2009. Centraal Bureau voor de Statistiek, Den Haag/Heerlen, The Netherlands.

Fairchild, J.K., Scogin, F.R., 2010. Training to Enhance Adult Memory (TEAM): an investigation of the effectiveness of a memory training program with older adults. Aging and Mental Health 14 (3), 364-373.

Glisky, E.L., 2007. Changes in cognitive function in human aging. In: Riddle, D. (Ed.), Brain Aging: Models, Methods, and Mechanisms. CRC Press, Boca Raton, FL.

Greenaway, M.C., et al., 2008. A behavioral rehabilitation intervention for amnestic mild cognitive impairment. American Journal of Alzheimer's Disease and Other Dementias 23 (5), 451-461.

Hampstead, B.M., et al., 2008. Explicit memory training leads to improved memory for face-name pairs in patients with mild cognitive impairment: results of a pilot investigation. Journal of the International Neuropsychological Society 14 (5), 883-889.

Hastings, E.C., West, R.L., 2009. The relative success of a self-help and a groupbased memory training program for older adults. Psychology and Aging 24 (3), 586-594

Jean, L., et al., 2010a. Cognitive intervention programs for individuals with mild cognitive impairment: systematic review of the literature. American Journal of Geriatric Psychiatry 18 (4), 281-296.

Jean, L., et al., 2010b. Efficacy of a cognitive training programme for mild cognitive impairment: results of a randomised controlled study. Neuropsychological Rehabilitation 20 (3), 377-405.

Joosten-Weyn Banningh, L.W., et al., 2008. A cognitive behavioural group therapy for patients diagnosed with mild cognitive impairment and their significant others: feasibility and preliminary results. Clinical Rehabilitation 22 (8), 731-740.

Kinsella, G.J., et al., 2009. Early intervention for mild cognitive impairment: a randomised controlled trial. Journal of Neurology, Neurosurgery and Psychiatry 80 (7), 730-736.

Klusmann, V., et al., 2010. Complex mental and physical activity in older women and cognitive performance: a 6-month randomized controlled trial. The Journal of Gerontology. Series A, Biological Sciences and Medical Sciences 65 (6), 680-688.

Klusmann, V., et al., 2011. Activity experiences shape perceived fitness trajectories: results from a 6-month randomized controlled trial in older women. Neuropsychology, Development, and Cognition. Section B, Aging, Neuropsychology and Cognition 18 (3), 328-339.

Li, S.C., et al., 2008. Working memory plasticity in old age: practice gain, transfer, and maintenance. Psychology and Aging 23 (4), 731-742.

Londos, E., et al., 2008. Effects of a goal-oriented rehabilitation program in mild cognitive impairment: a pilot study. American Journal of Alzheimer's Disease and Other Dementias 23 (2), 177-183.

Lustig, C., et al., 2009. Aging, training, and the brain: a review and future directions. Neuropsychology Review 19 (4), 504-522.

Martin, M., et al., 2011. Cognition-based interventions for healthy older people and people with mild cognitive impairment. Cochrane Database of Systematic Reviews 1, CD006220.

McDougall.JJr., G., et al., 2010. The SeniorWISE study: improving everyday memory in older adults. Archives of Psychiatric Nursing 24 (5), 291-306.

Mozolic, J.L., et al., 2011. A cognitive training intervention improves modalityspecific attention in a randomized controlled trial of healthy older adults. Neurobiology of Aging 32 (4), 655-668.

Noice, H., Noice, T., 2009. An arts intervention for older adults living in subsidized retirement homes. Neuropsychology, Development, and Cognition. Section B, Aging, Neuropsychology and Cognition 16 (1), 56-79.

Ozgis, S., Rendell, P.G., Henry, J.D., 2009. Spaced retrieval significantly improves prospective memory performance of cognitively impaired older adults. Gerontology 55 (2), 229-232.

Papp, K.V., Walsh, S.J., Snyder, P.J., 2009. Immediate and delayed effects of cognitive interventions in healthy elderly: a review of current literature and future directions. Alzheimers Dementia 5 (1), 50-60.

Richmond, L.L., et al., 2011. Working memory training and transfer in older adults Psychology and Aging 26 (4), 813-822.

Schmiedek, F., et al., 2010. Cognitive enrichment in old age web-based training programs. GeroPsychology 23 (2), 59-67.

Schulz, K.F., Altman, D.G., Moher, D., 2010. CONSORT 2010 statement: updated guidelines for reporting parallel group randomized trials. Annals of Internal Medicine 152 (11), 726-732.

Slegers, K., van Boxtel, M.P., Jolles, J., 2008. Effects of computer training and Internet usage on the well-being and quality of life of older adults: a randomized, controlled study. Journals of Gerontology. Series B, Psychological Sciences and Social Sciences 63 (3), 176-184. 
Slegers, K., van Boxtel, M., Jolles, J., 2009. Effects of computer training and internet usage on cognitive abilities in older adults: a randomized controlled study. Aging Clinical and Experimental Research 21 (1), 43-54.

Smith, G.E., et al., 2009. A cognitive training program based on principles of brain plasticity: results from the Improvement in Memory with Plasticity-based Adaptive Cognitive Training (IMPACT) study. Journal of the American Geriatrics Society 57 (4), 594-603.

Talib, L.L., et al., 2008. Cognitive training increases platelet PLA2 activity in healthy elderly subjects. Prostaglandins Leukotrienes and Essential Fatty Acids 78 (4-5), 265-269.

Tardif, S., Simard, M., 2011. Cognitive stimulation programs in healthy elderly: a review. International Journal of Alzheimers Disease, Article ID: 378934.

Teixeira, C.V., et al., 2012. Non-pharmacological interventions on cognitive functions in older people with mild cognitive impairment (MCI). Archives of Gerontology and Geriatrics 54 (1), 175-180.

Tranter, L.J., Koutstaal, W., 2008. Age and flexible thinking: an experimental demonstration of the beneficial effects of increased cognitively stimulating activity on fluid intelligence in healthy older adults. Neuropsychology, Development, and Cognition. Section B, Aging, Neuropsychology and Cognition 15 (2), 184-207.

Troyer, A.K., et al., 2008. Changing everyday memory behaviour in amnestic mild cognitive impairment: a randomised controlled trial. Neuropsychological Rehabilitation 18 (1), 65-88.

Tsolaki, M., et al., 2011. Effectiveness of nonpharmacological approaches in patients with mild cognitive impairment. Neurodegenerative Diseases 8 (3), 138-145.

Valenzuela, M., Sachdev, P., 2009. Can cognitive exercise prevent the onset of dementia? Systematic review of randomized clinical trials with longitudinal follow-up. American Journal of Geriatric Psychiatry 17 (3), 179-187.

Wagner, S., et al., 2008. Does a cognitive-training programme improve the performance of middle-aged employees undergoing in-patient psychosomatic treatment? Disability and Rehabilitation 30 (23), 1786-1793.

West, R.L., Bagwell, D.K., Dark-Freudeman, A., 2008. Self-efficacy and memory aging: the impact of a memory intervention based on self-efficacy. Neuropsychology, Development, and Cognition. Section B, Aging, Neuropsychology and Cognition 15 (3), 302-329. 